\title{
Lead removal from wastewater using fluted pumpkin seed shell activated carbon: Adsorption modeling and kinetics
}

\author{
${ }^{1}$ A. I. Okoye; ${ }^{1 *}$ P. M. Ejikeme; ${ }^{1,2}$ O. D. Onukwuli \\ ${ }^{1}$ Industrial and Biomass Laboratory, Department of Pure and Industrial Chemistry, University of Nigeria, \\ Nsukka, Nigeria \\ ${ }^{2}$ Department of Chemical Engineering, Nnamdi Azikiwe University, Awka, Nigeria
}

Received 26 December 2009; $\quad$ revised 2 Februaty 2010; accepted 2 June 2010; available online 1 September 2010

\begin{abstract}
Activated carbon produced from fluted pumpkin (Telfairia occidentalis) seed shell was utilized for the removal of lead (II) ion from simulated wastewater. Adsorption tests were carried out in series of batch adsorption experiments. Several kinetic models (Bhattacharya-Venkobacher, Elovich, pseudo first and second order, intra-particle and film diffusion) were tasted for conformity to the experimental data obtained. The Langmuir and Freundlich adsorption models were also used to test the data. The amount of lead (II) ion adsorbed at equilibrium from a 200 $\mathrm{mg} / \mathrm{L}$ solute concentration was $14.286 \mathrm{mg} / \mathrm{g}$. The experimental data conform very well to the pseudo-second order equation where equilibrium adsorption capacities increased with increasing initial lead (II) concentration. The rate of the adsorption process was controlled by the film (boundary layer) diffusion as the film diffusion co-efficient values obtained from data analysis were of the order of $10^{6} \mathrm{~cm}^{2} / \mathrm{s}$. From the plots, the linear regression coefficient $\left(\mathrm{R}^{2}\right)$ of the Langmuir model was higher than that of the Freundlich: the adsorption isotherm obeyed the Langmuir model better than the Freundlich model.
\end{abstract}

Key words: Film diffusion; Intraparticle diffusion; Isotherm; Kinetic model; Lead (II) ions; Sorption; Telfairia occidentalis

\section{INTRODUCTION}

In recent years, increasing awareness of water pollution and its far reaching effects has prompted concerted efforts towards pollution abatement (Donmez et al., 1999; Igbinosa and Okoh, 2009). The rate at which effluents are discharged into the environment and water bodies, has been on the increase due to rapid growth of cities in the world. Generally, water bodies are major sites of heavy metal deposits due to the fact that streams and rivers flow through agricultural areas where pesticides and fungicides may have been used, through industrial districts where there may have been many metal waste deposits or direct discharge of effluents into these water bodies (Malakootian et al., 2009). These metal pollutants are conservative contaminants that are not easily biodegradable chemically or biologically. They are therefore permanent chemical overload in the environment (El-Nady and Atta, 1996). When these metals are present in significant quantities in the

\footnotetext{
*Corresponding Author Email: ejikemepaul13@yahoo.com
} Tel./Fax: +2348035472743 environment, they constitute source of pollution and pollutants and pose threat to the environment, human, animal and aquatic lives. Removal of trace amounts of heavy metal ions from wastewater and drinking water is of great importance due to their high toxicity (AbdelGhani and Elchaghaby, 2007; Abdel-Ghani et al., 2009; Resmi et al., 2010).

Lead is of heavy metals with high toxicity when in excess. In children, lead causes a decrease in intelligent quotient (IQ) score, retardation of physical growth, hearing impairment, impaired learning, as well as decreased attention and classroom performance. In individuals of all ages, lead can cause anaemia, kidney malfunction, brain diseases and impaired function of peripheral nervous system, high blood pressure, reproduction abnormality, developmental defects, abnormal vitamin D metabolism, colic-like abnormal pains, dementia, madness and, in some situations, death (Okoro and Ejike, 2007). Lead as $\mathrm{Pb}^{2+}$ ion has a large affinity for the thio (-SH) and phosphate ion $\left(\mathrm{PO}_{4}\right)$ containing enzymes, ligands and biomolecules, thereby, 
inhibiting the biosynthesis of haeme units, affecting membrane permeability of kidney, liver and brain cells. These result in either reduced functions or complete breakdown of these organs. Lead forms complexes with oxo-groups in enzymes to affect virtually all steps in the process of heamoglobin synthesis and porphyrin metabolism (Ademoroti, 1996).

Adsorption is one of the easiest, safest and most cost-effective methods for the removal of these metals (Balkose and Baltacioglu, 1992; Shah et al., 2009; Rahmani et al., 2009). The major advantage of an adsorption system for water pollution control are less investment in terms of both initial cost and land, simple design and easy operation and no effect of toxic substances compared to conventional biological treatment processes (Markovska et al, 2006). Activated carbon has been used as an adsorbent for removal of heavy metal pollutants from wastewater and has proved to be effective (Gueu, et al., 2007; Goyal et al., 2008). This is due to its good adsorption properties which depend on its well developed porous structure and large active surface area (Kang et al., 2008). Also, it can be produced from cheap and locally available materials (Ochonogor and Ejikeme, 2005; Ejikeme and Ochonogor, 2008; Mahvi, 2008; Okpareke et al., 2009). Ion exchange resins have also been used to remove heavy metals from wastewater (Boldaji et al., 2009; Rafati et al., 2010). The potentials of activated carbon from the seed shell of fluted pumpkin (Telfairia Occidentalis) in accomplishing this pollution abatement is investigated in this work in laboratory. Kinetic and isotherm modeling were also carried out in the present study.

\section{MATERIALS AND METHODS}

Materials

Telfairia Occidentalis seed shells were collected in Nsukka environment, cleaned and ground. Particles passing through $1.75 \mathrm{~mm}$ sieve mesh size and retained in $1 \mathrm{~mm}$ sieve mesh size were used in this work. The activated carbon was produced using the method of Kongsuwan et al., (2006), with activation done by soaking the raw material in $60 \%$ by weight phosphoric acid for $24 \mathrm{~h}$. The product was washed with distilled water until the $\mathrm{pH}$ of the leachate was $\sim 6$. Then, it was dried in an air-drying oven at $105^{\circ} \mathrm{C}$ for $4 \mathrm{~h}$ and stored in a dessicator. Stock solution $(1000 \mathrm{mg} / \mathrm{L})$ of lead was prepared using lead nitrate $\left(\mathrm{Pb}\left(\mathrm{NO}_{3}\right)_{2}\right)$ and de-ionized water. All working solutions were prepared by proper dilution of the stock solution with de-ionized water.

\section{Sorption experiments}

Adsorption experiments were carried out by the batch process at a laboratory temperature of $30 \pm 1{ }^{\circ} \mathrm{C}$ for $4 \mathrm{~h}$ to ensure attainment of equilibrium. $2.0 \mathrm{~g}$ of adsorbent was added to $400 \mathrm{~mL}$ of adsorbate solutions of concentration $50,100,150$ and $200 \mathrm{mg} / \mathrm{L}$ and mixed at a constant agitation speed of $400 \mathrm{rpm}$ using an SM3 Stuart magnetic stirrer (Stuart Scientific Co. Ltd, Britain). $25 \mathrm{~mL}$ sample solution was withdrawn from the reaction mixture at fixed time intervals and filtered. The filtrates were then analyzed for residual metal concentration using an atomic absorption spectrometer (Buck Scientific, Model 210 VGP).

\section{Isotherm study}

The isotherm study was conducted by contacting $100 \mathrm{~mL}$ of adsorbates solution of concentration 50, 100, 150 and $200 \mathrm{mg} / \mathrm{L}$ with $0.5 \mathrm{~g}$ of adsorbent. At the end of $4 \mathrm{~h}$, the reaction mixture was filtered and the filtrates analyzed for residual metal concentrations.

\section{Kinetic models}

\section{Bhattacharya-Venkobachar model}

The Bhattacharya-Venkobachar equation is written as (Israel and Ekwumemgbo, 2008):

$\log [1-(U) T]=\left(k_{B} / 2.303\right) t$

Where, $(U) T=\left(C_{o}-C_{p}\right) /\left(C_{o}-C_{e}\right)$

$\mathrm{K}_{\mathrm{B}}$ is the Bhattacharya-Venkobachar's constant $(1 / \mathrm{min}) ; \mathrm{C}_{\mathrm{o}}$ is the initial concentration $(\mathrm{mg} / \mathrm{L}) ; \mathrm{C}_{\mathrm{t}}$ is the concentration at time $\mathrm{t}(\mathrm{mg} / \mathrm{L})$ and $\mathrm{C}_{\mathrm{e}}$ is the concentration at equilibrium $(\mathrm{mg} / \mathrm{L})$. A plot of $\log [1-$ (U)T] versus t should yield a straight line, if the sorption process obeys this model. From the slope of the plot, $\mathrm{K}_{\mathrm{B}}$ can be determined.

\section{Elovich model}

The Elovich equation (Sparks, 1986) is generally expressed as:

$d q_{t} / d t=\alpha \exp \left(-\beta q_{t}\right)$

Where, $\alpha$ is the initial adsorption rate $(\mathrm{mg} / \mathrm{g} / \mathrm{min})$ and $\alpha$ is desorption rate constant $(\mathrm{mg} / \mathrm{g} / \mathrm{min})$ during any one experiment. To simplify the Elovich equation, Chien and Clayton, (1980) assumed $\alpha \beta \mathrm{t}>>\mathrm{t}$ and by 
applying the boundary conditions $\mathrm{q}_{\mathrm{t}}=0$ at $\mathrm{t}=0$ and $\mathrm{q}_{\mathrm{t}}$ $=\mathrm{q}_{\mathrm{t}}$ at $\mathrm{t}=\mathrm{t}$, Eq. 3 yields Eq. 4 .

$q_{t}=(1 / \beta) \ln (\alpha \beta)+(1 / \beta) \ln (t)$

Thus, a plot of $\mathrm{q}_{\mathrm{t}}$ vs. In $(\mathrm{t})$ should yield a linear relationship with a slope of $(1 / \beta)$ and an intercept of $(1 /$ $\beta) \ln (\alpha \beta)$, if the sorption process fits the Elovich equation.

\section{Pseudo first order model}

The pseudo first order equation is generally expressed (Nassar, 1997) as:

$d q_{t} / d_{t}=k_{1}\left(q_{e}-q_{t}\right)$

Where, $q_{e}$ and $q_{t}$ are the adsorption capacity at equilibrium and at time $\mathrm{t}$, respectively $(\mathrm{mg} / \mathrm{g})$ and $\mathrm{k}_{1}$ is the rate constant of pseudo first order adsorption $(1 / \mathrm{min})$. After integration and applying boundary conditions, $\mathrm{t}=0$ to $\mathrm{t}=\mathrm{t}$ and $\mathrm{q}_{\mathrm{t}}=0$ to $\mathrm{q}_{\mathrm{t}}=\mathrm{q}_{\mathrm{t}}$, Eq. 5 takes the form of Eq. 6 .

$\log \left(q_{e}-q_{t}\right)=\log \left(q_{e}\right)-\left(k_{1} t\right) / 2.303$

A plot of $\log \left(q_{e}-q_{t}\right)$ versus $t$ should give a straight line, if the sorption is controlled by this model. $\mathrm{k}_{1}$ and $\mathrm{q}_{\mathrm{e}}$ can be determined from the slope and intercept of the plot, respectively. The major disadvantage with this model is that in most cases, the equation does not fit well for experimental data over the entire range of contact time (Ho and Mckay, 1999).

\section{Pseudo-second order model}

The pseudo second order adsorption kinetic rate equation as expressed by Ho et al., (2000) is

$d q_{t} / d t=k_{2}\left(q_{e}-q_{t}\right)^{2}$

Where, $\mathrm{k}_{2}$ is the rate constant of pseudo second order adsorption ( $\mathrm{mg} / \mathrm{g} / \mathrm{min})$. From the boundary conditions $\mathrm{t}=0$ to $\mathrm{t}=\mathrm{t}$ and $\mathrm{q}_{\mathrm{t}}=0$ to $\mathrm{q}_{\mathrm{t}}=\mathrm{q}_{\mathrm{t}}$, the integrated form of equation (7) yields Eq. 8.

$1 /\left(q_{e}-q_{t}\right)=1 / q_{e}+k_{2}$

This is the integrated rate law for a pseudo second order reaction. Eq. 8 can be rearranged to obtain Eq. 9, which has a linear form.

$t / q_{t}=1 /\left(k_{2} q_{e}^{2}\right)+t / q_{e}$
A plot of $t / q_{t}$ versus $t$ should give a straight line, if this model is obeyed by the sorption process. From the slope and intercept of the plots, $\mathrm{q}_{\mathrm{e}}$ and $\mathrm{k}_{2}$ are determined, respectively.

\section{Intra-particle and film diffusion kinetics}

The basic assumption with intra-particle diffusion model is that film diffusion is negligible and intraparticle diffusion is the only rate-controlling step (Venkata et al, 2008). According to Weber and Morris, (1963), if the rate limiting step is the intra-particle diffusion, then the amount adsorbed at any time $\mathrm{t}$ should be directly proportional to the square root of contact time, $t$ and shall pass through the origin. This is defined mathematically as:

$q_{t}=k_{i d} t^{0.5}$

Where $\mathrm{q}_{\mathrm{t}}(\mathrm{mg} / \mathrm{g})$ is the amount adsorbed at time $\mathrm{t}(\mathrm{min})$ and $\mathrm{k}_{\mathrm{id}}\left(\mathrm{mg} / \mathrm{g} / \mathrm{min}^{-0.5}\right)$ is the intra-particle rate constant. The logarithmic form of Eq. 10 is Eq. 11.

$\log q_{t}=\log k_{i d}+0.5 \log t$

The plot of $\log \mathrm{q}_{\mathrm{t}}$ against $0.5 \log \mathrm{t}$ should yield a straight line with a positive intercept for intra-particle diffusion controlled adsorption process. $\mathrm{k}_{\mathrm{id}}$ is determined from the intercept of the plot. Higher values of $\mathrm{K}_{\text {id }}$ illustrate an enhancement in the rate of adsorption. To confirm whether an adsorption process is controlled by intra-particle diffusion or film diffusion, the intra-particle diffusion coefficient, $\mathrm{D}_{\mathrm{p}}$ and the film diffusion coefficients, $\mathrm{D}_{\mathrm{F}}$ are usually calculated from Eq. 12 and 13, respectively.

$D_{P}=\left(0.03 r_{0}^{2}\right) / t_{0.5}$

Where ' $\mathrm{r}_{0}$ ' $(\mathrm{cm})$ is the average radius of the adsorbent particle and $\mathrm{t}_{0.5}(\mathrm{~min})$ is the time required to complete the half of the adsorption.

$D_{F}=\left(0.23 r_{0} \Gamma C_{S}\right) /\left(C_{L} t_{0.5}\right)$

Where $\delta$ is the film thickness $\left(10^{-3} \mathrm{~cm}\right), \mathrm{C}_{\mathrm{S}}$ and $\mathrm{C}_{\mathrm{L}}$ are the concentrations of adsorbate in solid and liquid phase at time $t$, respectively. If the calculated intraparticle diffusion coefficient $(\mathrm{Dp})$ value are in the range of $10^{-11}$ to $10^{-13} \mathrm{~cm}^{2} / \mathrm{s}$, then the intra-particle diffusion 
will be the rate determining step and, if the calculated film diffusion co-efficient $\left(\mathrm{D}_{\mathrm{F}}\right)$ value is in the range of $10^{-6}$ to $10^{-8} \mathrm{~cm}^{2} / \mathrm{s}^{-1}$, then the rate limiting step will be controlled by film (boundary layer) diffusion (Debnath and Gosh, 2008).

\section{Isotherms Langmuir isotherm}

The Langmuir isotherm is usually expressed (Patel and Suresh, 2008) as:

$q_{e}=\left(q_{\max } C_{e}\right) /\left(K_{L}+C_{e}\right)$

Where, $\mathrm{q}_{e}$ is the equilibrium value of adsorbate adsorbed per unit weight of adsorbent $(\mathrm{mg} / \mathrm{g}), \mathrm{q}_{\max }$ is the maximum amount of adsorption corresponding to monomolecular layer coverage $(\mathrm{mg} / \mathrm{g}), \mathrm{C}_{\mathrm{e}}$ is the equilibrium concentration of the adsorbate, $\mathrm{k}_{\mathrm{L}}$ is the Langmuir's constant and is related to the measure of affinity of the adsorbate for the adsorbent $(\mathrm{L} / \mathrm{mg})$. For correlation purposes, the equation is rearranged as shown in equation (15).

$C_{e} / q_{e}=\left(1 / k_{L} \cdot q_{\max }\right)+\left(1 / q_{\max }\right) \cdot C_{e}$

A linearized plot of $\mathrm{C}_{\mathrm{e}}$ " $\mathrm{q}_{\mathrm{e}}$ against $\mathrm{C}_{\mathrm{e}}$ yields a straight line graph which has an intercept and slope which correspond to $\left(1 / \mathrm{k}_{\mathrm{L}} / \mathrm{q}_{\max }\right)$ and $\left(1 / \mathrm{q}_{\max }\right)$, respectively, from which the $\mathrm{q}_{\max }$ and $\mathrm{k}_{\mathrm{L}}$ can be calculated. To confirm the favourability of an adsorption process to Langmuir isotherm, the essential features of the isotherm can be expressed in terms of a dimensionless constant separation factor or equation parameter, $\mathrm{R}_{\mathrm{L}}$, which can be calculated as:

$R_{L}=1 /\left(1+k_{L} \cdot C_{o}\right)$

Where, $\mathrm{C}_{\mathrm{o}}$ is the initial adsorbate concentration. The value of $R_{L}$ indicates whether the isotherm is irreversible $\left(\mathrm{R}_{\mathrm{L}}=0\right)$, favourable $\left(0<\mathrm{R}_{\mathrm{L}}<1\right)$, linear $\left(\mathrm{R}_{\mathrm{L}}=1\right)$ or unfavourable $\left(\mathrm{R}_{\mathrm{L}}>1\right)$ (Kadirvelu and Namasivayam, 2003).

\section{Freundlich Isotherm}

The Freundlich relationship is given as:

$q_{e}=k_{F} \cdot C_{e}^{1 / n}$

Where, $1 / \mathrm{n}$ is a heterogeneity factor, which is a measure of intensity of sorption or affinity of the adsorbate for the adsorbent and is less than 1 if the adsorption process is favourable; $k_{F}$ is the
Freundlich constant, which is a measure of adsorption capacity (mg/g) (Faust and Osman, 1987). The Freundlich equation can be linearized as shown in Eq. 18.

$\log q_{e}=\log k_{F}+1 / n \log C_{e}$

The constants, $\mathrm{k}_{\mathrm{F}}$ and $\mathrm{n}$, are determined by plotting $\log \mathrm{C}$ on the abscissa and $\log \mathrm{q}_{\mathrm{e}}$ on the ordinate. A best fit of the experimental data provides values for $n$ and $\mathrm{k}_{\mathrm{F}}$ based on the slope and the y-intercept, respectively.

\section{RESULTS AND DISCUSSION}

Effects of contact time and initial metal ion concentration

Fig. 1 shows the dependence of the amount of metal adsorbed on contact time and initial metal ion concentration. There was an initial rapid sorption for about 50 min of agitation after which the rate of sorption became slower. After $130-170$ min of agitation, equilibrium was attained. The rapid initial sorption was likely due to extra-cellular binding and the slower sorption likely resulted from intracellular binding (Ferguson et al, 1989) as the carbon surfaces were being covered. The plots of metal uptake as a function of time are single, smooth and continuous leading to saturation. This suggests possible monolayer coverage of the metal ions on the surface of the adsorbent (Pimentel et al., 2008). The amount of metal adsorbed per unit weight of carbon was found to increase with increase in metal concentration as increased initial

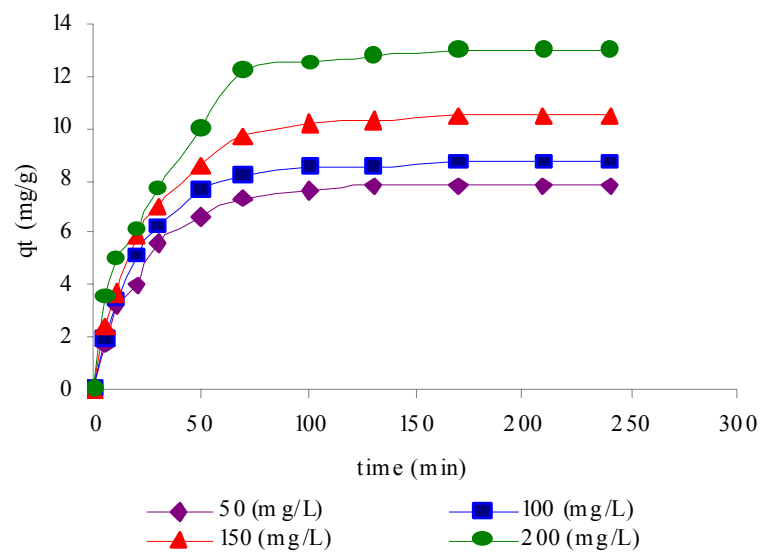

Fig. 1: Effect of contact time and initial concentration of $\mathrm{Pb}$ (II) ions 
Int. J. Environ. Sci. Tech., 7 (4), 793-800, Autumn 2010

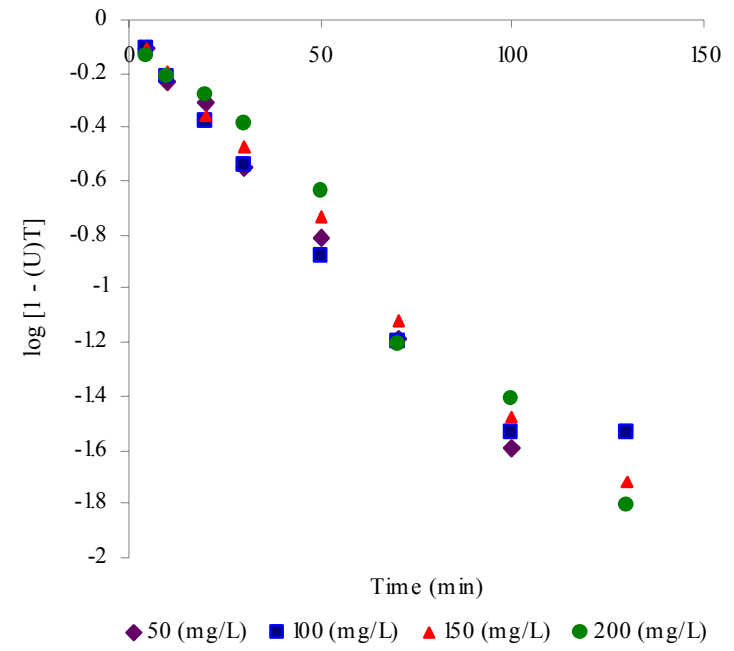

Fig. 2: Bhattacharya-Venkobachar plot for $\mathrm{Pb}$ (II) ion adsorption

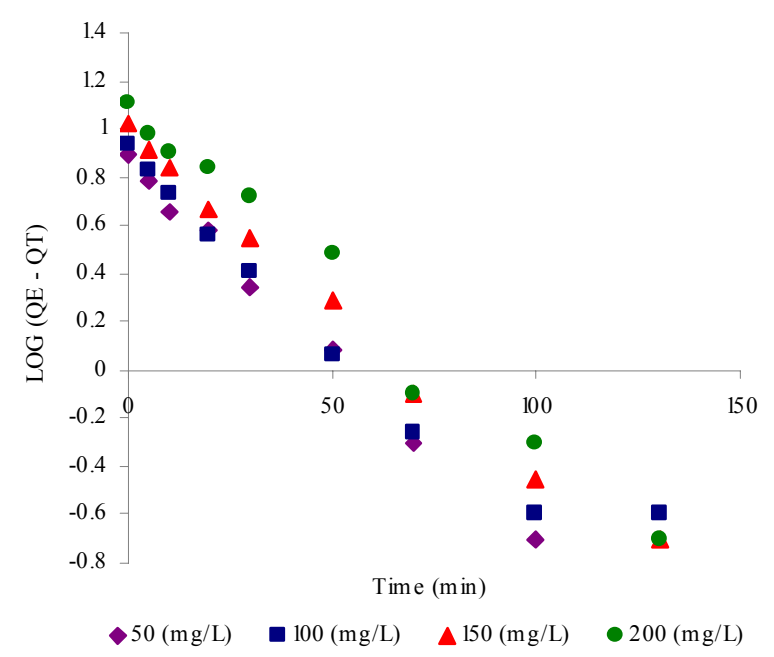

Fig. 4: Pseudo first order plot for $\mathrm{Pb}$ (II) ion adsorption

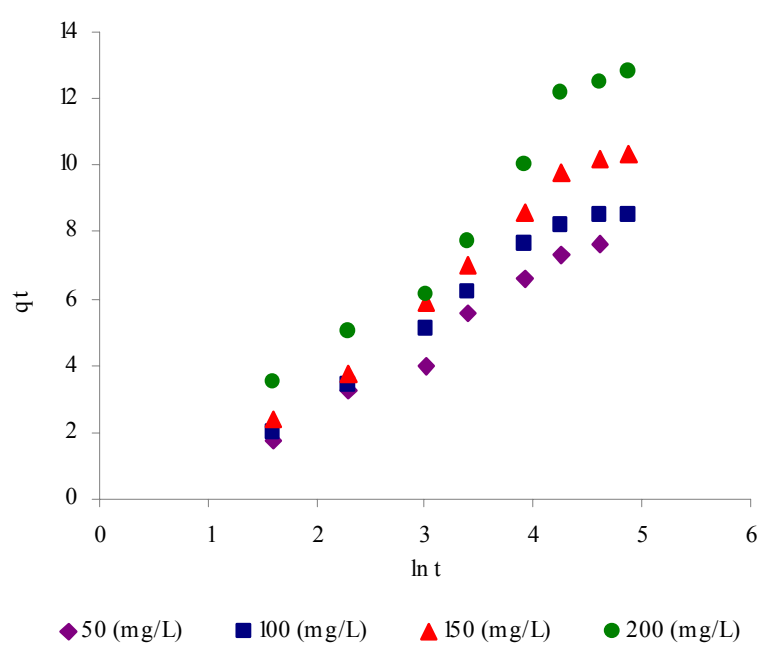

Fig. 3: Elovich plot for $\mathrm{Pb}$ (II) ion adsorption

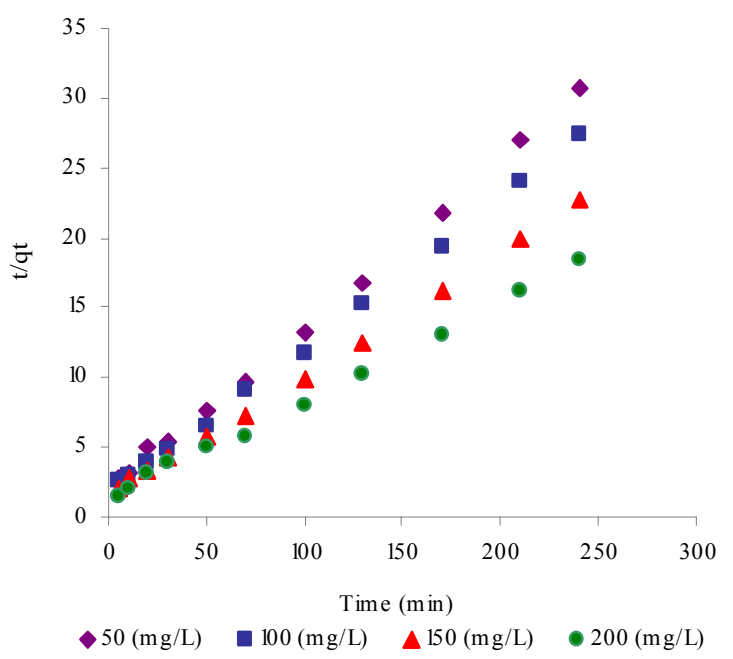

Fig. 5: Pseudo second order plot for $\mathrm{Pb}$ (II) ion adsorption

Table 1: The kinetic parameters evaluated for $\mathrm{Pb}$ (II) Ion adsorption

\begin{tabular}{|c|c|c|c|c|c|}
\hline \multirow{2}{*}{ Kinetic model } & \multirow{2}{*}{ Parameter } & \multicolumn{4}{|c|}{ Solute concentration $(\mathrm{mg} / \mathrm{L})$} \\
\hline & & 50 & 100 & 150 & 200 \\
\hline \multirow{2}{*}{$\begin{array}{l}\text { Bhattacharya- } \\
\text { Venkobachar }\end{array}$} & $\mathrm{K}_{\mathrm{B}}\left(\min ^{-1}\right)$ & -0.035 & -0.028 & -0.030 & -0.030 \\
\hline & $\mathrm{R}^{2}$ & 0.995 & 0.943 & 0.989 & 0.979 \\
\hline \multirow{3}{*}{$\begin{array}{l}\text { Pseudo-first } \\
\text { order }\end{array}$} & $\mathrm{K}_{1}\left(\min ^{-1}\right)$ & -0.035 & -0.028 & -0.030 & -0.032 \\
\hline & $\mathrm{q}_{\mathrm{e}}(\mathrm{mg} / \mathrm{g})$ & 7.194 & 6.668 & 9.183 & 12.134 \\
\hline & $\mathrm{R}^{2}$ & 0.995 & 0.948 & 0.989 & 0.981 \\
\hline \multirow{3}{*}{ Elovich } & $\alpha(\mathrm{mg} / \mathrm{g} / \mathrm{min})$ & 0.945 & 1.144 & 1.242 & 1.540 \\
\hline & $\beta(\mathrm{mg} / \mathrm{g} / \mathrm{min})$ & 0.490 & 0.462 & 0.379 & 0.318 \\
\hline & $\mathrm{R}^{2}$ & 0.982 & 0.977 & 0.988 & 0.964 \\
\hline \multirow{3}{*}{$\begin{array}{l}\text { Pseudo- } \\
\text { second order }\end{array}$} & $\begin{array}{l}\mathrm{K}_{2} \\
(\mathrm{~g} / \mathrm{mg} / \mathrm{min})\end{array}$ & 0.0075 & 0.0066 & 0.0049 & 0.0037 \\
\hline & $\mathrm{q}_{\mathrm{e}}(\mathrm{mg} / \mathrm{g})$ & 8.475 & 9.524 & 11.628 & 14.286 \\
\hline & $\mathrm{R}^{2}$ & 0.997 & 0.999 & 0.998 & 0.996 \\
\hline
\end{tabular}


concentrations increased the driving force (Kilic et al., 2008; Zvinowanda et al., 2009).

\section{Kinetic studies}

The Bhattacharya-Venkobachar plots at various concentrations are shown in Fig. 2, while the Elovich, pseudo first order and second order plots are shown in Figs. 3, 4 and 5, respectively. A comparison of the kinetic models using the linear regression coefficient $\left(\mathrm{R}^{2}\right)$ values (Table 1) shows that the pseudo second order

Table 2: The Intra-particle and film diffusion parameters evaluated for $\mathrm{Pb}$ (II) ion adsorption

\begin{tabular}{lrrrr}
\hline \multirow{2}{*}{ Parameter } & \multicolumn{4}{c}{ Solute concentration $(\mathrm{mg} / \mathrm{L})$} \\
\cline { 2 - 5 } & 50 & 100 & 150 & 200 \\
\hline $\mathrm{K}_{\mathrm{id}}\left(\mathrm{mg} / \mathrm{g} . \mathrm{min}^{-0.5}\right)$ & 0.933 & 1.035 & 1.300 & 1.828 \\
$\mathrm{D}_{\mathrm{P}}\left(\mathrm{cm}^{2} / \mathrm{s}\right)$ & $9.66 \times 10^{-4}$ & $9.33 \times 10^{-4}$ & $1.32 \times 10^{-3}$ & $5.57 \times 10^{-4}$ \\
$\mathrm{D}_{\mathrm{F}}\left(\mathrm{cm}^{2} / \mathrm{s}\right)$ & $6.89 \times 10^{-6}$ & $2.92 \times 10^{-6}$ & $3.14 \times 10^{-6}$ & $1.20 \times 10^{-6}$ \\
$\mathrm{R}^{2}$ & 0.950 & 0.950 & 0.961 & 0.979 \\
\hline
\end{tabular}

Table 3: The Langmuir isotherm parameters evaluated for $\mathrm{Pb}$ (II) ion adsorption

\begin{tabular}{ll}
\hline Parameter & Value \\
\hline $\mathrm{k}_{\mathrm{f}}(\mathrm{mg} / \mathrm{g})$ & 1.614 \\
$\mathrm{n}$ & 1.678 \\
\hline
\end{tabular}

Table 4: The Fruendlich isotherm parameters evaluated for $\mathrm{Pb}(\mathrm{II})$ Ion adsorption

\begin{tabular}{lr}
\hline Parameter & Value \\
\hline $\mathrm{K}_{\mathrm{L}}(\mathrm{L} / \mathrm{mg})$ & 0.04 \\
$\mathrm{q}_{\mathrm{m}}(\mathrm{mg} / \mathrm{g})$ & 13.70 \\
$\mathrm{R}_{\mathrm{L}}$ & 0.111 \\
\hline
\end{tabular}

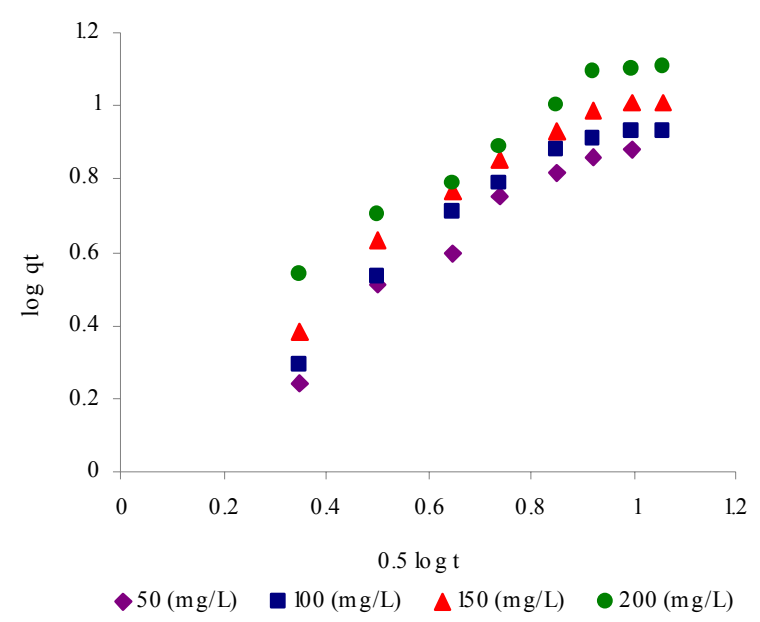

Fig. 6: Weber and Morris (1963) plot for $\mathrm{Pb}$ (II) ion adsorption model best describes the adsorption processes $\left(\mathrm{R}^{2}>\right.$ 0.995). Vinodhini and Das, (2010) also reported a pseudo second order kinetics for the removal of chromium (VI) ions from aqueous solutions. The experimental $\mathrm{q}_{\mathrm{e}}$ were found to be close to the estimated one, increasing with increasing concentration. Values of $\mathrm{k}_{2}$ were found to decrease with increasing initial metal ion concentration which suggests increased adsorption (Debnath and Gosh, 2008).

\section{Intra-particle and film dffusion kinetics}

The Weber and Morris plots (Fig. 6) are not completely linear suggesting that intra-particle diffusion is not the rate determining step. Also, the values of the intra-particle diffusion coefficients, $D_{P}$ are not in the range of $10^{-11}$ to $10^{-13} \mathrm{~cm}^{2} / \mathrm{s}$ but $10^{-3}$ to

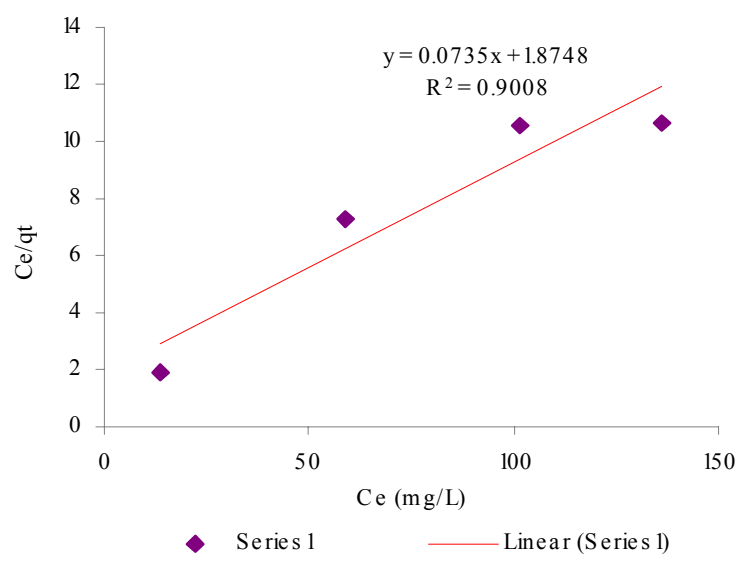

Fig. 7: Langmuir isotherm for $\mathrm{Pb}$ (II) ion adsorption

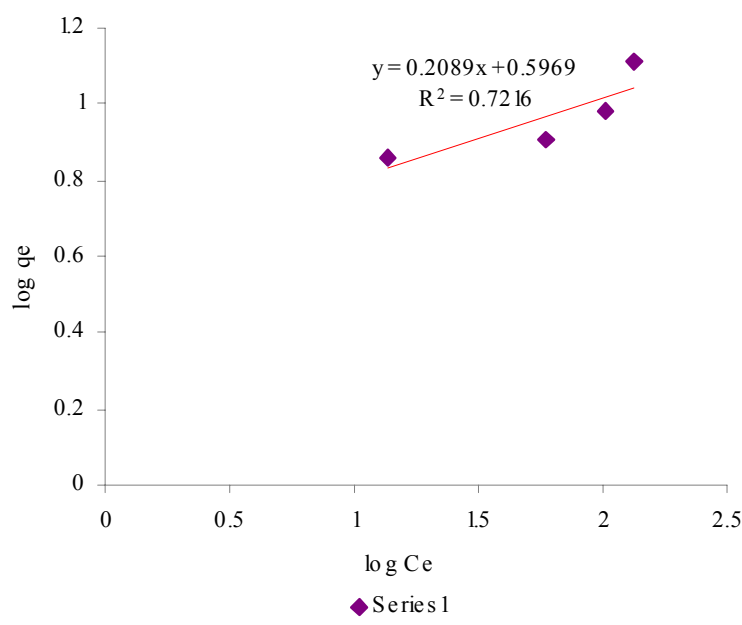

Fig. 8: Freundlich isotherm for $\mathrm{Pb}$ (II) ion adsorption 
$10^{-4} \mathrm{~cm}^{2} / \mathrm{s}$ (Table 2). This confirms that the particle diffusion is not the rate determining step. However, the film diffusion co-efficient $\left(\mathrm{D}_{\mathrm{F}}\right)$ values are of the order of $10^{-6} \mathrm{~cm}^{2} / \mathrm{s}$ (Table 2) showing that the rate limiting step is be controlled by film (boundary layer) diffusion.

\section{Isotherm study \\ Langmuir isotherm}

The Langmuir plot is shown in Fig. 7 and the values of the constants are shown in Table 3. The graph is linear, with a reasonably high linear regression coefficient $\left(\mathrm{R}^{2}\right)$ value $(0.900)$ suggesting that the adsorption process obeys the Langmuir model. Also, the $R_{L}$ value is 0.111 , showing that the Langmuir isotherm is favourable (Mattson and Mark, 1971). Therefore, the adsorption of $\mathrm{Pb}$ (II) on the activated carbon can be said to be monolayer-type and this agrees with the observation that the adsorption from an aqueous solution usually forms a layer on the adsorbent surface.

\section{Freundlich isotherm}

The plot of Freundlich equation is shown in Fig. 8 and the values of the constants are shown in Table 4. The linear regression coefficient $\left(\mathrm{R}^{2}\right)$ value is comparatively low (0.721) suggesting that this model is not so suitable for the description of the adsorption process.

\section{CONCLUSION}

The experimental results obtained in this work show the possibility of producing activated carbons with good adsorption capacity from Telfairia Occidentalis seed shell. The kinetic data agree very well with the pseudo-second order equation and the rate is film (boundary layer) diffusion controlled. Isotherm analysis showed that the adsorption process described Langmuir Isotherm better than the Freundlich Isotherm.

\section{REFERENCES}

Abdel-Ghani, N. T.; Elchaghaby, G. A., (2007). Influence of operating conditions on the removal of $\mathrm{Cu}, \mathrm{Zn}, \mathrm{Cd}$ and $\mathrm{Pb}$ ions from wastewater by adsorption. Int. J. Environ. Sci. Tech., 4 (4), 451-456 (6 pages).

Abdel-Ghani, N. T.; Hegazy, A. K.; El-Chaghaby, G. A., (2009). Typha domingensis leaf powder for decontamination of aluminium, iron, zinc and lead: Biosorption kinetics and equilibrium modeling. Int. J. Environ. Sci. Tech., 6 (2), 243248 (6 pages).
Ademoroti, C. M. A., (1996). Environmental chemistry and toxicology. Pollution by heavy metals. Foludex press, 171172 (2 pages).

Balkose, D.; Baltacioglu, H., (1992). Adsorption of heavy metal cations from aqueous solution by wool fiber. J. Chem. Tech. Biotech., 54 (4), 393-397 (6 pages).

Boldaji, M. R.; Mahvi, A. H.; Dobaradaran, S.; Hosseini, S. S., (2009). Evaluating the effectiveness of a hybrid sorbent resin in removing fluoride from water. Int. J. Environ. Sci. Tech., 6 (4), 629-632 (4 pages)

Chien, S. H.; Clayton, W. R., (1980). Application of elovich equation to the kinetics of phosphate release and sorption on soils. Soil Sci. Soc. Am. J., 44 (2), 265-268 (4 pages).

Debnath, S.; Ghosh, U. C., (2008). Kinetics, isotherm and thermodynamics for $\mathrm{Cr}$ (III) and $\mathrm{Cr}$ (VI) adsorption from aqueous solutions by crystalline hydrous titanium oxide. J. Chem. Thermodynam., 40 (1), 67-77 (11 pages).

Dönmez, G.; Aksu, Z.; Özturk A.; Kutsal, T., (1999). A comparative study on heavy metal biosorption characteristic of some algae. Process. Biochem., 34 (9), 885-892 (8 pages).

Ejikeme, P. M.; Ochonogor, A. E., (2008). Adsorption kinetics of basic violet-1 removal by Penthaclethra mycrophylla woody-pod activated carbon. J. Chem. Soc. Nig., 33 (1), 132-137 (6 pages).

El-nady, F. E.; Atta, M. M., (1996). Toxicity and bioaccumulation of metals in some marine biota from Egyptian coastal waters. J. Environ. Sci. Health, A-31 (7), 1529-1545 (6 pages).

Faust, S. D.; Osman, M. A., (1987). Adsorption process for water treatment. Butterworths, London.

Ferguson, M. R.; Peterson, T. M.; Jeffers, A., (1989). In: Scheiner, B. J.; Doyle, F. M.; Kawerta, S. K. (Eds.), Proceedings of 1989 SME Symposium on Biotechnology in Minerals and Metal Processing, 24.

Goyal, P.; Sharma, P.; Srivastava, S.; Srivastava, M. M., (2008). Saraca indica leaf powder for decontamination of lead: removal, recovery, adsorbent characterization and equilibrium modeling. Int. J. Environ. Sci. Tech., 5 (1), $27-$ 34 (8 pages).

Gueu, S.; Yao, B.; Adouby, K.; Ado, G., (2007). Kinetics and thermodynamics study of lead adsorption on to activated carbons from coconut and seed hull of the palm tree. Int. J. Environ. Sci. Tech. 4 (1), 11-17 (6 pages).

Ho, Y. S.; John Wase, D. A.; Forster, C. F., (2000). Study of the sorption of divalent metal ions onto peat. Adsorpt. Sci. Tech., 18 (7), 639 - 650 (12 pages).

Ho, Y. S.; Mckay, G., (1999). Pseudo second order model for sorption processes. Proc. Biochem., 34 (5), 451-465 (15 pages).

Igbinosa, E. O.; Okoh, A. I., (2009). Impact of discharge wastewater effluents on the physico-chemical qualities of a receiving watershed in a typical rural community. Int. J. Environ. Sci. Tech., 6 (2), 175-182 (8 pages).

Israel, O. K.; Ekwumemgbo, P. A., (2008). Kinetics of the removal of ovalbumin from white wine model solution. Book of Proceedings, Chemical Society of Nigeria, Egboh, S. H. O. (Ed.), Warri, Nigeria, 413-418.

Kadirvelu, K.; Namasivayam, C., (2003). Activated carbon from coconut coir pith as metal adsorbent: Adsorption of Cd (II) from aqueous solution. Adv. Environ. Res., 7 (2), 471-478 (9 pages). 
Kang, K. C.; Kim, S. S.; Choi, J. W.; Kwon, S. H., (2008). Sorption of $\mathrm{Cu}^{2+}$ and $\mathrm{Cd}^{2+}$ onto acid and base-pretreated granular activated carbon and activated carbon fiber samples. J. Ind. Eng. Chem., 14 (1), 131-135 (5 pages).

Kiliç, M.; Keskin, M. E.; Mazlum S.; Mazlum, N., (2008). Effect of conditioning for $\mathrm{Pb}$ (II) and $\mathrm{Hg}$ (II) biosorption on waste activated sludge. Chem. Eng. Proc., 47 (1), 31-40 (10 pages).

Kongsuwan, A.; Patnukao, P.; Pavasant, P., (2006). Removal of metal ion from synthetic waste water by activated carbon from Eucalyptus camaldulensis Dehn bark The $2^{\text {nd. }}$ Joint International Conference on Sustainable Energy and Environment (SEE 2006).

Mahvi, A. H., (2008). Application of agricultural fibers in pollution removal from aqueous solution. Int. J. Environ. Sci. Tech., 5 (2), 275-285 (11 pages).

Malakootian, M.; Nouri, J.; Hossaini, H., (2009). Removal of heavy metals from paint industries wastewater using Leca as an available adsorbent. Int. J. Environ. Sci. Tech., 6 (2), 183-190 (8 pages).

Markovska, L. T.; Meshko, V. D.; Marinkovski., (2006). Modeling of adsorption kinetics of zinc onto granular activated carbon and natural zeolite. J. Serb. Chem. Soc., 71 (8), 957-967 (11 pages).

Mattson, J. S.; Mark, H. B., (1971). Activated carbons: Surface chemistry and adsorption from solution. Marcel Dekker, New York.

Nassar, M. M., (1997). The kinetics of basic dye removal using palm fruit bunch. Adsorpt. Sci. Tech., 15 (8), 609617 (9 pages).

Ochonogor, A. E.; Ejikeme, P. M., (2005). Adsorption potentials of Cinnarium schweinfurthi nut shell activated carbon. J. Chem. Soc. of Nig., 30 (2), 91-95 (5 pages).

Okoro, I. A.; Ejike, E. N., (2007). Sorption models of Pb (II) removal from aqueous solution using common edible fruit wastes. Eur. J. Sci. Res., 17 (2), 270-276 (7 pages).

Okpareke, O. C.; Agha I. I.; Ejikeme, P. M., (2009). Removal of $\mathrm{Cu}$ (II), Cd (II) and $\mathrm{Hg}$ (II) ions from simulated waste water by Brachystagea Eurycoma seed pod: Intraparticle diffusivity and sorption studies, Paper presented at the $32^{\text {nd. }}$ International Conference of the Chemical Society of
Nigeria, Bauchi.

Patel, R.; Suresh, S., (2008). Kinetic and equilibrium studies on the biosorption of reactive black 5 dye by Aspergillus foetidus. Bioresour. Tech., 99 (1), 51-58 (8 pages).

Pimentel, P. M.; Melo, M. A. F.; Melo, D. M. A.; Assução, A. L. C.; Henrique, D. M.; Silva Jr. C. N.; González, G., (2008). Kinetics and thermodynamics of $\mathrm{Cu}$ (II) adsorption on oil shale wastes. Fuel Process. Tech., 89 (1), 62-67 (6 pages).

Rafati, L.; Mahvi, A. H.; Asgari, A. R.; Hosseini, S. S., (2010). Removal of chromium (VI) from aqueous solutions using Lewatit FO36 nano ion exchange resin. Int. J. Environ. Sci. Tech., 7 (1), 147-156 (10 pages).

Rahmani, K.; Mahvi, A. H.; Vaezi, F.; Mesdaghinia, A. R.; Nabizade, R.; Nazmara, S., (2009). Bioremoval of lead by use of waste activated sludge. Int. J. Environ. Res., 3 (3), 471-476 (6 pages).

Resmi, G.; Thampi, S. G.; Chandrakaran, S., (2010). Brevundimonas vesicularis check for this species in other resources: A novel bio-sorbent for removal of lead from wastewater. Int. J. Environ. Res., 4 (2), 281-288 (8 pages).

Shah, B. A.; Shah, A. V.; Singh R. R., (2009). Sorption isotherms and kinetics of chromium uptake from wastewater using natural sorbent material. Int. J. Environ. Sci. Tech., 6 (1), 77-90 (14 pages).

Sparks, D. L., (1986). Kinetics of reaction in pure and mixed systems in Soil Physical Chemistry, Boca Raton: CRC Press, 12-18.

Venkata Mohan, S.; Ramanaiah, S. V.; Sarma, P. N., (2008). Biosorption of direct azo dye from aqueous phase onto Spirogyra sp. 102: Evaluation of kinetics and mechanistic aspects. Biochem. Eng. J., 38 (1), 61-69 (9 pages).

Vinodhini, V.; Das, N., (2010). Relevant approach to assess the performance of sawdust as adsorbent of chromium (VI) ions from aqueous solutions. Int. Environ. Sci. Tech., 7 (1), 85-92 (8 pages).

Weber, W. J.; Morris, J. C., (1963). Kinetics of adsorption on carbon from solution. J. Sanit. Eng. Div. Am. Soc. Civ. Eng., 89 (1), 31-60 (30 pages).

Zvinowanda, C. M.; Okonkwo, J. O.; Shabalala, P. N.; Agyei, N. M., (2009). A novel adsorbent for heavy metal remediation in aqueous environments. Int. J. Environ. Sci. Tech., 6 (3), $425-434$ (10 pages).

\footnotetext{
AUTHOR (S) BIOSKETCHES

Okoye, A. I., M.Sc., Department of Pure and Industrial Chemistry of the University of Nigeria, Nsukka, Nigeria.

Email: okoyeai@yahoo.com

Ejikeme, P. M., Ph.D. Candidate, Lecturer, Department of Pure and Industrial Chemistry of the University of Nigeria, Nsukka, Nigeria. Email: ejikemepaul13@yahoo.com

Onukwuli, O. D., Ph.D., Professor, Nnamdi Azikiwe University, Awka-Nigeria; an Adjunct Professor in the Department of Pure and Industrial Chemistry of the University of Nigeria, Nsukka, Nigeria. Email: onukwuliod@yahoo.com
}

How to cite this article: (Harvard style)

Okoye, A. I.; Ejikeme, P. M.; Onukwuli, O. D., (2010). Lead removal from waste water using fluted pumpkin seed shell activated carbon Adsorption modeling and kinetics. Int. J. Environ. Sci. Tech., 7 (4), 793-800. 